\title{
HUBUNGAN KADAR APOLIPOPROTEIN B DENGAN TEKANAN DARAH SISTOLIK DAN DIASTOLIK PADA DEWASA MUDA OBESITAS DAN NON OBESITAS
}

\author{
$\underline{\text { Abi Bakring Balyas }}{ }^{1}$, Atifah Darwis ${ }^{2}$ \\ 1. Pendidikan Dokter, Fakultas Kedokteran, Universitas Palangka Raya, Palangka Raya, Indonesia \\ 2. Fisioterapi, Fakultas Kedokteran, Universitas Hasanuddin, Makassar, Indonesia \\ E-mail: abibakringb@gmail.com
}

\begin{abstract}
ABSTRAK
Obesitas dapat mempengaruhi kadar apolipoprotin B dalam darah sehingga mempengaruhi kadar kolesterol dan menyebabkan dislipidemia, arterosklerosis, hingga hipertensi. Penelitian ini bertujuan membuktikan adanya hubungan antara kadar apolipoprotein B dengan tekanan darah sistolik dan tekanan darah diastolik. Metode penelitian yang digunakan adalah desain potong lintang (cross sectional) dengan jumlah sampel 60 dewasa muda, yang terdiri atas 30 dewasa muda obesitas dan 30 dewasa muda non-obesitas. Pemilihan sampel menggunakan teknik purposif. Kategori lingkar pinggang ditentukan berdasarkan penilaian Waist Circumference menurut WHO. Kriteria IMT ditentukan berdasarkan standar antropometri Penilaian Status Gizi Kriteria Asia Pasifik dari WHO. Hasil penelitian menunjukkan bahwa ada korelasi kadar apolipoprotein B dengan tekanan darah sistolik dan tekanan darah sistolik. Terdapat korelasi positif antara kadar polipoprotein B dengan tekanan darah diastolik.
\end{abstract}

Kata kunci: Apolipoprotein B, Tekanan Darah Sistolik, tekanan Darah Diastolik

\begin{abstract}
Obesity can affect apolipoprotein B level of blood thus affecting cholesterol level and can cause dyslipidemia, atherosclerosis, and hypertension. This research aimed to prove the relation between the apolipoprotein $B$ levels with systolic and diastolic blood pressure.. The research method was the cross-sectional design and and the samplkes comprised 60 young adults: 30 obesity yaoung adults and 30 non-obesity young adults. The samples was chosen using the purposive sampling technique. The category of the waist circumference was determined using WHO waist circumference assessment criteria of WHO. The research results revealed that there was relation between the apolipoprotein A-I levels and systolic blood pressure of young adults. there was relation between the apolipoprotein A-I levels and diastolic blood pressure of young adults.

(kosong satu spasi tunggal $10 \mathrm{pt}$ )
\end{abstract}

Keywords: Apolipoprotein B, Sysstolic Blood Pressure, Diastolic Bloodd Pressure. 


\section{PENDAHULUAN}

Penyakit jantung koroner (PJK) dan gagal jantung merupakan masalah kesehatan yang termasuk sering ditemukan dan menjadi penyakit penyebab kematian nomor 1 di dunia. Sekitar 13,2\% kematian di dunia disebabkan oleh penyakit jantung iskemik atau penyakit jantung koroner. Penyebab terjadinya PJK dan gagal jantung itu sendiri sangat bervariasi mulai dari penyumbatan arteri koronaris, hipertensi, abnormalitas katup jantung, faktor genetis, kebiasaan merokok, diabetes, disfungsi ginjal, hingga obesitas (Mosterd and Hoes, 2007). Obesitas berarti penimbunan lemak yang berlebih di dalam tubuh. Obesitas disebabkan oleh pemasukan jumlah makanan yang lebih besar daripada pemakaiannya oleh tubuh sebagai energi (Guyton, 2012). Obesitas sendiri telah menjadi masalah epidemik di berbagai belahan dunia termasuk indonesia dan prevalensi terus meningkat pada tingkat yang cepat di berbagai populasi dan di semua kelompok umur. Pada tahun 2014, World Health Organization (WHO) mengindikasikan bahwa lebih dari 1,9 miliar orang dewasa, 18 tahun ke atas, mengalami overweight. Dari jumlah tersebut, lebih dari 600 juta orang mengalami obesitas. Data tersebut juga menunjukkan sebesar 39\% dewasa umur 18 tahun ke atas mengalami overweight dan $13 \%$ diantaranya sudah termasuk obesitas (WHO, 2015).

Obesitas pada orang dewasa merupakan faktor yang sering dikaitkan dengan mortalitas dan morbiditas (Ebong et al., 2014). Tingginya angka mortalitas pada orang yang mengalami obesitas disebabkan banyaknya gangguan kesehatan yang dapat ditimbulkan. Resiko gangguan kesehatan yang dapat disebabkan oleh obesitas antara lain ialah hipertensi, diabetes melitus, penyakit jantung koroner, gagal jantung kongestif, stroke, batu ginjal, osteoarthritis, gangguan tidur, kanker, hingga yang paling sering terjadi ialah gejala dislipidemia (Pi-Sunyer et al., 2003).

Dislipidemia merupakan gejala yang sering terjadi pada individu obesitas. Gejala ini dapat dilihat dari peningkatan kadar trigliserida dan asam lemak bebas, peningkatan kolesterol total, peningkatan kadar kolesterol Low Density Lipoprotein (LDL), serta penurunan kadar kolesterol High Density Lipoprotein (HDL) (Klop et al., 2013).

Ada hubungan yang signifikan antara Kadar Kolesterol dengan Kadar Hipertensi. Selanjutnya dari output diatas diketahui Correlation Coefficient (koefisien korelasi) sebesar 0,668 maka nilai ini menandakan hubungan yang tinggi antara kadar kolesterol dengan tekanan darah pada penderita hipertensi di Dusun Sidomulyo Desa Rejoagung. Kolesterol tinggi (hiperkolesterolemia) akan menimbulkan masalah terutama pada pembuluh darah dan otak. Jika kadar kolesterol melebihi batas normal akan menyebabkan aterosklerosis. Aterosklerosis akan menyumbah pembuluh darah arteri (Maryati, 2012).

Berdasarkan beberapa penelitian yang telah dilakukan di atas, obesitas ternyata dapat mempengaruhi kadar LDL dalam darah sehingga menyebabkan dislipidemia, arterosklerosis, hipertensi hingga penyakit jantung koroner. Walaupun demikian penelitian tentang hubungan LDL dengan kejadian hipertensi lebih banyak dilakukan daripada penelitian hubungan antara kadar apolipoprotein B dengan kejadian hipertensi sehingga membuat peneliti tertarik untuk meneliti apakah kadar apolipoprotein B juga berpengaruh terhadap tekanan darah individu utamanya yang masih dalam usia dewasa muda. Tujuan penelitian ini adalah membuktikan adanya hubungan kadar apolipoprotein B dengan tekanan darah sistolik dan diastolik pada dewasa muda.

\section{METODE PENELITIAN}

Desain Penelitian

Desain penelitian yang digunakan adalah studi potong lintang (Cross Sectional Study).

Lokasi dan Waktu Penelitian

Penelitian dilakukan di dua tempat, yaitu Fakultas Kedokteran Universitas Hasanudin untuk pengukuran tekanan darah serta pengambilan sampel darah dan laboratorium klinik parahita makassar untuk analisis kadar apolipoprotein B . Waktu Penelitian mulai bulan Mei 2015 sampai dengan Juni 2015.

Populasi dan Sampel

Populasi adalah seluruh mahasiswi yang berusia 1824 tahun. Sampel sebanyak 60 orang Dewasa muda dipilih secara purposive sampling yang telah memenuhi kriteria inklusi yaitu bersedia menjadi responden dan berumur 1824 tahun.

Sumber Data

Data diperoleh secara langsung melalui pengukuran kadar apolipoprotein B dan tekanan darah secara langsung.

Pengumpulan Data

Pengukuran kadar apolipoprotein B plasma darah pada sampel penelitian. Pengambilan sampel darah vena sebanyak 10 cc untuk pemeriksaan kadar keduanya. Pengambilan sampel dilakukan pada pagi hari yaitu antara pukul 09.00 - 10.00 setelah berpuasa selama 12 jam Kadar apolipoprotein B $(\mathrm{mg} / \mathrm{dl})$ diperiksa dengan menggunakan metode imunoturbidimetri.

Analisis Data

Data yang diperoleh diolah dengan menggunakan SPSS for windows 16.0, lalu dianalisis dengan tingkat kemaknaan $\leq 0,05$. Untuk mengetahui hubungan kadar apolipoprotein B dengan tekanan darah sistolik dan diastolik, dilakukan uji korelasi pearson.. 


\section{HASIL DAN PEMBAHASAN}

Tabel 1. Distribusi karakteristik sampel penelitian

\begin{tabular}{|l|l|l|l|l|l|l|}
\hline Umur (thn) & 60 & 20,18 & 2,01 & 18 & 24 & 19,50 \\
\hline BB $(\mathrm{kg})$ & 60 & 60,07 & 19,74 & 36 & 128 & 58 \\
\hline TB $(\mathrm{m})$ & 60 & 1,54 & 0,05 & 1,44 & 1,69 & 1,54 \\
\hline IMT $\left(\mathrm{kg} / \mathrm{m}^{2}\right)$ & 60 & 25,04 & 7,44 & 15,3 & 44,9 & 24,09 \\
\hline LP $(\mathrm{cm})$ & 60 & 79,35 & 16,38 & 58 & 112 & 79,50 \\
\hline TDS (mm Hg) & 60 & 115,08 & 13,01 & 80 & 140 & 112,5 \\
\hline \begin{tabular}{l} 
TDD $(\mathrm{mm} \mathrm{Hg})$ \\
\hline $\begin{array}{l}\text { Kadar Apolipoprotein B } \\
(\mathrm{mg} / \mathrm{dl})\end{array}$
\end{tabular} & 60 & 76,08 & 9,66 & 50 & 110 & 72,5 \\
\hline
\end{tabular}

Pada tabel 1 dapat dilihat bahwa rerata umur responden adalah 20,18 $(\mathrm{SD}=2,01)$, rerata tinggi badan responden adalah $1,54(\mathrm{SD}=0,05)$, dan rerata berat badan responden adalah $60,07(\mathrm{SD}=19,74)$. Adapun karakteristik responden berdasarkan Indeks Massa Tubuh (IMT) adalah rerata $25,04(\mathrm{SD}=7,44)$, rerata lingkar pinggang adalah $79,35 \quad(\mathrm{SD}=16,38)$ sedangkan karakteristik responden berdasarkan kadar apolipoprotein B rerata 88,23 $(\mathrm{SD}=25,20)$. Pada tabel 1 , terlihat juga bahwa rerata tekanan darah sistolik 115,08 ( $\mathrm{SD}=13,01)$ sedangkan rerata tekanan darah diastolik 76,08 ( $\mathrm{SD}=9,66)$.

\section{Korelasi Kadar Apolipoprotin B terhadap Tekanan Darah Sistolik dan Diastolik}

Tabel 2 Korelasi Kadar Apolipoprotein B terhadap $\underline{\text { Tekanan Darah Sistolik dan Diastolik pada Dewasa Muda }}$

\begin{tabular}{lll}
\hline \multirow{2}{*}{ Variabel } & \multicolumn{2}{l}{ Kadar Apolipoprotein B } \\
\cline { 2 - 3 } & Nilai r & Nilai p \\
\hline Tekanan Darah & 0,346 & 0,007 \\
$\begin{array}{l}\text { Sistolik (mm Hg) } \\
\text { Tekanan Darah }\end{array}$ & 0,296 & 0,022 \\
Diastolik & & \\
\hline
\end{tabular}

Pearson Correlation test (1-tailed); $p$ signifikan bila $p$ $\leq 0,05$

Dari tabel 2 terlihat bahwa dengan uji korlasi pearson untuk mengetahui hubungan antara kadar apolipoprotein B dengan tekanan darah sistolik diperoleh angka signifikansi sebesar 0,007 yang berarti bahwa ada hubungan linier yang signifikan antara kadar apolipoprotein B dengan tekanan darah sistolik. Nilai koefisien korelasi sebesar 0,346 menunjukkan bahwa arah korelasi positif dengan kekuatan korelasi yang cukup. Arti korelasi positif berarti semakin tinggi kadar apolipoprotein B maka semakin tinggi juga tekanan darah sistolik. Dari tabel 2 juga terlihat bahwa dengan uji korelasi pearson untuk mengetahui hubungan antara kadar apolipoprotein B dengan tekanan darah diastolik diperoleh angka signifikansi sebesar 0,022 yang berarti bahwa ada hubungan linier yang signifikan antara kadar apolipoprotein B dengan tekanan darah diastolik. Nilai koefisien korelasi sebesar 0,296. Menunjukkan bahwa arah korelasi positif dengan kekuatan korelasi yang juga cukup kuat. Korelasi positif berarti semakin kadar apolipoprotein B maka semakin tinggi juga tekanan darah diastolik..

\section{PEMBAHASAN}

Hasil penelitian menunjukkan setelah dilakukan uji analisis hubungan antara kadar apolipoprotein B dengan tekanan darah sistolik menunjukkan hubungan linier yang signifikan antara kadar apolipoprotein B dengan tekanan darah sistolik $(\mathrm{p}=0,007)$. Kekuatan korelasi yang didapatkan cukup ( $r=-0,346)$. Arah korelasi positif berarti dewasa muda yang memiliki kadar apolipoprotein B yang tinngi juga memiliki tekanan darah sistolik lebih tinggi dibandingkan dengan dewasa muda dengan kadar apolipoprotein B yang normal. Hasil penelitian ini sesuai dengan hasil penelitian yang dilakukan oleh Li et al (2017), bahwa apo B memiliki hubungan yang linier dengan tekann darah.

ApoB disintesis oleh hati dan disekresikan dengan VLDL. Ini pada gilirannya dikonversi di periferal menjadi lipoprotein densitas menengah (IDL) dan kemudian ke LDL. nampaknya, apoB secara signifikan terkait dengan risiko PJK bahkan setelah penyesuaian 
untuk LDL-C, meskipun korelasi yang sangat tinggi antara kedua variabel (Pischon et al, 2005). Peran apo B sangat penting dalam aterosklerosis karena dapat berikatan dengan reseptor LDL di endotel, mengakibatkan LDL tertahan didalam dinding pembuluh darah. Low density lipoproteins kemudian akan teroksidasi menjadi oxidized LDL (oxLDL) yang pada akhirnya akan memicu terjadinya aterosklerosis (Onat et al, 2007).

Hasil penelitian juga menunjukkan setelah dilakukan uji analisis hubungan antara kadar apolipoprotein B dengan tekanan darah diastolik menunjukkan hubungan linier yang signifikan antara kadar apolipoprotein B dengan tekanan darah diastolik $(\mathrm{p}=0,022)$. Kekuatan korelasi yang didapatkan cukup ( $\mathrm{r}=-$ 0,296 ). Arah korelasi positif berarti dewasa muda yang memiliki kadar apolipoprotein B yang tinngi juga memiliki tekanan darah diastolik lebih tinggi dibandingkan dengan dewasa muda dengan kadar apolipoprotein B yang normal. Hal ini juga sesuai dengan penelitian yang dilakukan Li et al (2017) yang menyatakan bahwa kadar apolipoprotein B berhubungan dengan tekanan darah diastolik pada berbagai umur dan ras. Guyton (2012) menyatakan bahwa apolipoprotein B merupakan apolipoprotein utama penyusun LDL dan VLDL. LDL ini kemudian berperan dalam menyebabkan arterosklerosis yang akhirnya dapat meningkatkan tekanan darah rata-rata.

\section{KESIMPULAN}

Dari penelitian ini disimpulkan bahwa terdapat hubungan kadar apolipoprotein B dengan tekanan darah sistolik dan diastolik. Pada dewasa muda obesitas, sebaiknya dilakukan penyuluhan tentang gizi yang seimbang.

\section{DAFTAR PUSTAKA}

Mosterd A. and Hoes A.W. (2007). Clinical Epidemiology of Heart Failure. Heart Journal 29 : 1137-1146.

Guyton A.C., dan Hall. (2012). Fisiologi Kedokteran Edisi 11. Jakarta: EGC

WHO. (2015). Obesity and Overweight. Media Centre.

Ebong I.A., Jr D.C.G., Rodriguez C.J., Chen H., Bertoni A.G. (2014). Mechanism of Heart Failure in Obesity. Obesity Research \& Clinical Practice, 8:540-548.

Pi-Sunyer F.X., Becker D.M., Bouchard C., Colditz G.A., Dietz W.H., Foreyt J.P., et al. (2003). Clinical Guidelines on The Idenstification, Evaluation, and treatment of OverWeight and Obesity in Adults. NIH Publication.
Klop B., Elte J.W.F., Cabezas M.C. (2013). Dyslipidemia in Obesity: Mechanisms and Potential Targets. Nutrients, 5: 12181240.

Maryati, H. 2017. Hubungan Kadar Kolesterol dengan Tekanan Darah Penderita Hipertensi di Dusun Sidomulyo Desa Rejoagung Kecamatan Ploso Kabupaten Jombang. E-Journal UMM 8 (2) : 2.

Li W., Yu Y., Liang D., Jia E. (2017). Factors Associated with Blood Pressure Variability Based on Ambulatory Blood Pressure Monitoring in Subjects with Hypertension in China. Kidney and Blood Pressure Research 42 : 267-275.

Onat A., Can G., Hergenc G., Yazici M., Karabulut A., Albayrak S. 2007. Serum apolipoprotein B predicts dyslipidemia, metabolic syndrome and, in women, hypertension and diabetes, independent of markers of central obesity and inflammation. Int J Obest. pp: 1119-25.

Pischon T., Girman C.J., Sacks F.M., Rifai N., Stampfer M.J., Rimm E.B. (2005). Non-High-Density Lipoprotein Cholesterol and Apolipoprotein B in the Prediction of Coronary Heart Disease in Men. Circulation 112:3375-3383. 